\title{
ОСОБЕННОСТИ ДЕМОГРАФИЧЕСКИХ ПРОЦЕССОВ В ЕВРОПЕЙСКОЙ РОССИИ В ХVIII-XІХ ВЕКАХ: ОПЫТ АНАЛИЗА МЕТРИЧЕСКИХ КНИГ ТРЕХ ПРАВОСЛАВНЫХ ПРИХОДОВ
}

\author{
ВЛАС РЯЗАНОВ
}

\begin{abstract}
В статье рассмотрены метрические книги трех православных сельских приходов в географически разных частях Европейской России (35 тыс. записей о рождении, браке и смерти) как источник информации о демографии страны середины XVIII - середины XIX веков. Результать обработки метрик дают оценку динамики общего сочиально-экономического благополучия населения России в этот временной отрезок, при котором периоды улучшения всех демографических показателей чередуются с кризисами разной продолжительности и интенсивности. Эти процессы в различной степени отражались на отдельных территориях. Из трех приходов лучшую динамику демонстрирует приход в Нечерноземье вне пригородной зоны Москвы, показатели для прихода в Черноземье ухудшает высокая смертность детского и взрослого населения, а для подмосковного прихода характерно более позднее вступление в брак. Поскольку все три прихода представляют сельское русское православное население, эти различия могут быть объяснены иными социиокультурными особенностями указанных местностей.
\end{abstract}

Ключевые слова: Россия, историческая демография 18 и 19 веков, брачность, рождаемость, смертность, метрические книги.

\section{ВВЕДЕНИЕ}

Историческая демография является областью междисциплинарных исследований на стыке истории, демографии, социологии, культурологии и ряда других сфер науки. Анализ пространственной динамики демографических показателей важен и для географических исследований, причем не только в контексте собственно исторической географии, но и как инструмент изучения «зависимости от пройденного пути» (англ. path dependency). Последняя влияет и на современные социально-экономические процессы.

Актуальность настоящего исследования для России и других стран с взаимосвязанными экономическим и демографическими проблемами связана с поиском внеэкономических факторов, которые влияют на ключевые демографические процессы вступление в брак, рождаемость и смертность. Анализ архивных демографических данных доиндустриальной эпохи позволяет исключить фактор урбанизации, который рассматривается как основной в демографических теориях, в первую очередь в теории демографического перехода.

ВЛАС АЛЕКСАНДРОВИч РЯЗАНОВ (vlas.ryazanov@gmail.com), ИНСТИТУТ ЭКОНОМИКИ РАН, РосСия.

СТАТЬЯ ПОСТУПИЛА В РЕДАКЦИЮ В ИЮНЕ 2021 Г. 
Исследования об исторической демографии России начали появляться еще в конце XIX века по мере накопления агрегированной государственными органами статистики. Они опирались на доклады и отчеты профильных учреждений. Схожий подход использовался в советский период, когда исследования в этом направлении, как и гуманитарная наука в целом, имели выраженную политическую окраску ${ }^{1}$ Работа с источниками первичной информации была затруднена недостаточной открытостью и доступностью архивов в советский период, уничтожением властями части дореволюционных документов ${ }^{2}$. Ситуация резко изменилась в 1990-е и 2000-е годы, когда источники первичной демографической информации в архивах стали доступнее для исследователей. Это позволило говорить даже о появлении в стране новой исторической демографии (Владимиров, Сарафанов, Щетинина 2016).

Ситуация в российском архивном деле хотя и медленно, но улучшается (Рязанов, Денисенко 2019), но к прорыву в историко-демографических исследованиях это пока не привело. Несмотря на доступность уже достаточно большого массива источников первичной демографической информации дореволюционного времени (ревизские сказки, исповедные ведомости, метрические книги), значительная часть работ по исторической демографии Российской империи по-прежнему представляет собой описательные источниковедческие труды. Ученые, которые занимаются исследованиями в данной области, в целом критически оценивают состояние этой сферы науки в России. Ключевые проблемы, на которые обращают внимание - сохраняющиеся сложности с доступом к данным региональных архивов, неготовность к использованию математических методов обработки, верификации и анализа данных, практически полное отсутствие государственного финансирования этого направления исследований (Владимиров, Сарафанов, Щетинина 2019). Как следствие, копирование, расшифровка и анализ архивных источников демографической информации больше распространены в среде исследователей-генеалогов, где интерес к этим трудоемким действиям подпитывает желание узнать имена предков и подробности их жизни.

Наиболее детальным источником первичной демографической информации данных о рождении, браке и смерти - являются метрические книги. Несмотря на давнее внимание к ним научного сообщества (Винник 2012b), подробных и, что крайне важно, опубликованных исследований приходов с опорой на сплошной массив расшифрованных и оцифрованных метрических книг немного. Наиболее известные были выполнены по Выхинской вотчине Шереметьевых Московской губернии за период 1815-1917 гг. (А. Авдеев, А. Блюм, И. Троицкая) и по Покровскому приходу города Барнаул за 1877-1886 гг. (М. Винник). Накопление и интеграция результатов изучения метрических книг в перспективе позволит восстановить целостную картину демографических процессов в России XVIII-XIX веков в пространстве и времени, поскольку, как справедливо отмечено

\footnotetext{
${ }^{1}$ В 1931-1941 гг. нынешний Российский государственный архив древних актов в Москве назывался «архив феодально-крепостнической эпохи».

${ }^{2}$ В частности, бюллетенем Центрархива РСФСР от 25 мая 1927 г. было предписано уничтожение исповедных ведомостей 1865 г. и более поздних как «не имеющих исторической ценности», хотя они были единственными регулярными срезами населения после прекращения сбора ревизских сказок.
} 
наблюдателями, они отличались неравномерностью и большой географической изменчивостью (Миронов 2005).

\section{ИСТОЧНИКИ ИНФОРМАЦИИ}

Основой публикуемого исследования были данные метрических книг трех приходов в Европейской России в 1758-1862 гг. Все три прихода составляло сельское русское православное население, однако географически они представляют собой разные местности - Нечерноземье, дальний пригород Москвы и центральное Черноземье (таблица 1).

Таблица 1. Сведения об исследуемых приходах

\begin{tabular}{|c|c|c|c|}
\hline & Яринское & Бисерово & Снежеток \\
\hline Храм прихода & $\begin{array}{l}\text { Успения Божьей } \\
\text { Матери }\end{array}$ & Богоявления Господня & Архангела Михаила \\
\hline АТД до губ. реформы1775 г. & $\begin{array}{l}\text { Дмитровский уезд, } \\
\text { Троицкий стан }\end{array}$ & $\begin{array}{l}\text { Московский уезд, } \\
\text { Почернев стан }\end{array}$ & $\begin{array}{l}\text { Козловский уезд, } \\
\text { Иловайский стан }\end{array}$ \\
\hline АТД после реформы1775 г. & $\begin{array}{l}\text { Тверская губерния, } \\
\text { Калязинский уезд }\end{array}$ & $\begin{array}{l}\text { Московская губерния, } \\
\text { Богородский уезд }\end{array}$ & $\begin{array}{l}\text { Рязанская губерния, } \\
\text { Раненбургский уезд }\end{array}$ \\
\hline АТД современное & $\begin{array}{l}\text { Тверская область, } \\
\text { Калязинский район }\end{array}$ & $\begin{array}{l}\text { Московская область, } \\
\text { Ногинский район }\end{array}$ & $\begin{array}{l}\text { Липецкая область, } \\
\text { Чаплыгинский район }\end{array}$ \\
\hline Диапазон метрических книг & $\begin{array}{l}1760-1862 \text { гг., } \\
11 \text { пропусков (нет) }\end{array}$ & $\begin{array}{l}\text { 1777-1862 гг., } \\
16 \text { пропусков (не выд.) }\end{array}$ & $\begin{array}{l}\text { 1758-1862 гг., } \\
12 \text { пропусков (нет) }\end{array}$ \\
\hline Записи о рождении, всего & 8554 & 3952 & 6413 \\
\hline Записи о браке, всего & 2107 & 786 & 1392 \\
\hline Записи о смерти, всего & 5777 & 2878 & 3329 \\
\hline Имя матери ребенка & С 1789 г. & С 1831 г. & С 1831 г. \\
\hline Возраст новобрачных & С 1839 г. & С 1839 г. & 1802-1830, с 1834 г. \\
\hline Причины смерти & 1774-1787, с 1808 г. & С 1823 г. & С 1807 г. \\
\hline Состав прихода & $\begin{array}{l}\text { Помещичьи крестьяне, } \\
\text { основа - вотчина } \\
\text { Сабуровых в сельце } \\
\text { Подол с деревнями }\end{array}$ & $\begin{array}{l}\text { Вотчина московского } \\
\text { Спасо-Андроникова } \\
\text { монастыря (далее } \\
\text { экономические) }\end{array}$ & $\begin{array}{l}\text { Однодворцы, } \\
\text { помещичьи крестьяне, } \\
\text { в том числе вотчина } \\
\text { Шишкиных в сельце } \\
\text { Знаменка }\end{array}$ \\
\hline $\begin{array}{l}\text { Опорные срезы населения за } \\
\text { период }\end{array}$ & $\begin{array}{l}\text { РС 1762-1858 гг. } \\
\text { (вотчина Сабуровых) }\end{array}$ & $\begin{array}{l}\text { РС } 1762,1773,1811- \\
1858 \text { гг., ПП } 1869 \text { г. } \\
\text { +ИВ } 1786 \text { и } 1799 \text { гг. }\end{array}$ & $\begin{array}{l}\text { РС 1762-1858 гг. (одн.) } \\
\text { РС 1762-1850 (Шишк.) }\end{array}$ \\
\hline Заселение & Ранее XVI века & Ранее XV века & $\begin{array}{l}\text { 1710-е (однодворцы), } \\
1720-50-е \text { (помещичьи } \\
\text { крестьяне), к } 1744 \text { село }\end{array}$ \\
\hline Местная география прихода & $\begin{array}{l}\text { На тракте Сергиев } \\
\text { Посад - Калязин }\end{array}$ & $\begin{array}{l}\text { Село на Бисерове } \\
\text { озере, деревни на } \\
\text { Владимирском и } \\
\text { Носовихинском } \\
\text { трактах }\end{array}$ & $\begin{array}{l}\text { На небольшом } \\
\text { удалении от уездного } \\
\text { города Раненбург }\end{array}$ \\
\hline $\begin{array}{l}\text { Темпы естественного } \\
\text { прироста населения в год по } \\
\text { данным ревизий, \% }\end{array}$ & $\begin{array}{l}1762-1782 \text { гг. }-1,08 \\
1782-1795 \text { гг. }-0,94 \\
1795-1811 \text { гг. }-1,46 \\
1811-1816 \text { гг. }-(0,82) \\
1816-1834 \text { гг. }-1,74 \\
1834-1850 \text { гг. }-0,97\end{array}$ & $\begin{array}{l}1762-1773 \text { гг. }-(0,98) \\
1773-1795 \text { гг. }-1,03 \\
1795-1811 \text { гг. }-1,44 \\
1811-1816 \text { гг. }-(0,32) \\
1816-1834 \text { гг. }-1,18 \\
1834-1850 \text { гг. }-0,63\end{array}$ & $\begin{array}{l}1762-1782 \text { гг. }-0,25 \\
1782-1795 \text { гг. }-1,21 \\
1795-1811 \text { гг. }-(0,02) \\
1811-1816 \text { гг. }-(0,52) \\
1816-1834 \text { гг. }-1,11 \\
1834-1850 \text { гг. }-0,72\end{array}$ \\
\hline
\end{tabular}

Примечание: АТД - административно-территориальное деление; РС-ревизская сказка; ППподворная перепись; ИВ - исповедная ведомость. В строке «Темпы естественного прироста населения в год по данным ревизий» в скобках указаны отрищательные значения 
Документированная история всех трех сел начинается задолго до рассматриваемого периода, при этом если приходы Бисерова и Яринского представляют собой давно заселенную местность Московской Руси, то военно-земледельческое освоение центрального Черноземья (приход Снежетка) вновь началось лишь в середине XVII века со строительством в Диком Поле крепостей Белгородской засечной черты. Культурные особенности этого многоэтничного фронтира были сформированы ценностными установками пионерного однодворческого населения, для которого земледелие изначально было вторичным и малопрестижным занятием в сравнении с военным делом.

Помимо неполноты информации, давно отмеченной критиками (Миронов 1998) и обычной для любых исторических источников, метрические книги содержат ошибки и неточности. Информацию из книг (записи о рождении, бракосочетании и смерти) автор проверял с опорой на интегрированные им срезы населения (данные ревизских сказок и исповедных ведомостей, подворных переписей). Наличие сплошного массива ревизских сказок является полезной особенностью именно этого временного интервала, но не более позднего периода (последняя ревизия прошла в 1858 г.). Помимо альтернативного и более точного источника информации об именах членов семей (так удалось восстановить 80\% имен матерей детей в вотчине Бисерова уже в 1790-е годы), срезы населения в дополнение к метрическим книгам содержат данные о половозрастной структуре приходов, а также наличии и устойчивости фамилий. В частности, в приходе Снежетка фамилии уже в XVIII веке были устойчивыми не только у однодворцев, у которых они были всегда, но также у крестьян, что говорит о важности патрилинейного родства и общем патриархальном характере семей. В приходах Бисерова и Яринского, напротив, фамилии были неустойчивы даже в XIX веке. При этом ярким феноменом вотчины Бисерова было большое число незамужних и бездетных взрослых женщин, живших с родителями или братьями - следствие позднего вступления в брак мужского населения и его более высокой смертности. Девочки, пережившие эпидемию чумы 1771-72 гг., которая привела к дефициту потенциальных женихов, стали первым поколением, многие представители которого так и не смогли выйти замуж и создали прецедент массового девства. Откладывание вступления в брак мужчинами в приходе также впервые отмечается уже в 1770-е годы, что могло быть связано с развитием ткацкого дела в этой местности в то время ${ }^{3}$.

Приход Яринского выделяется среди других тем, что с середины XVIII века был двуклирным, т. е. состоял из двух общин при одном и том же храме, возглавляемых разными священниками. Ситуация в Яринском, где у прихожан была потребность в двойном штате духовенства, резко контрастирует с положением дел в Снежетке. Там каменный храм за 2 века так и не был построен, а в 1767 г. священник расписался в метрических книгах за дьячка, потому что тот не умел писать.

\footnotetext{
${ }^{3}$ В 1766 г. правительство Екатерины II снизило экспортные пошлины на зерно, что вызвало двукратный за десятилетие рост цен на хлеб в России. Для малоплодородного востока Подмосковья это было особенно болезненно, и крестьяне начали подрабатывать надомным ткачеством, которое было в 1767 г. легализовано. До XX века оно было преимущественно мужским занятием, о чем говорит и подворная перепись 1869-71 гг.
} 
Результаты настоящего исследования были доложены автором на семинаре Института демографии ВШЭ в декабре 2020 г., презентация доклада и ссылка на видеозапись были размещены на портале «Демоскоп» ${ }^{4}$. Презентация содержит ряд дополнительных графиков, которые иллюстрируют описываемые в статье выводы, но не включены в нее из-за ограничений по объему. Это графики нарушений брачного возраста, отношения чисел рождений и браков, внебрачной рождаемости и ее структуры, отношения числа умерших до возраста 10 лет к числу родившихся, факторов детской и младенческой смертности, смертности от внешних причин, инфляции возраста пожилых умерших в приходе Снежетка, половозрастной структуры вотчины Бисерова. После семинара база источников первичной информации была расширена за счет ряда недостающих метрических книг, что качественно не сказалось на полученных выводах, но увеличило их достоверность. Часть описываемых далее показателей была дополнительно агрегирована автором по десятилетиям (Приложение). Все первичные источники информации (своды метрических книг и своды срезов населения по трем приходам) размещены автором на портале «Всероссийское генеалогическое древо» ${ }^{5}$ в открытом доступе.

\section{БРАКИ}

Сезонность заключения браков (совершение венчания) определялась правилами Православной Церкви, которые исключают венчания в посты, на Святки, а также в Светлую и мясопустную седмицы. Прочее время календарного года может быть условно разделено на зиму (январь-март, до Великого поста), весну (апрель-июнь, после Великого и до Петрова поста), лето (июль и август), осень (сентябрь-ноябрь, до Рождественского поста). С практической точки зрения заключение браков в каждый из этих периодов имело определенные преимущества и недостатки для сельского населения. Осенние свадьбы проходили после сбора урожая при максимальных запасах продовольствия, но добавляли в семьи едоков. Зимние предшествовали рекомендованному Церковью воздержанию по время Великого поста, а затем началу цикла полевых работ. Весенние проходили при минимальных запасах, но добавляли работниц непосредственно перед хозяйственным сезоном. Летние могли совпадать по времени с уборкой урожая или отходом на заработки мужского населения. Анализ сезонности венчаний (рисунок 1) показывает минимальное число браков летом во всех трех приходах в течение всего рассматриваемого периода. Также во всех трех приходах в XVIII веке наиболее популярны были осенние браки, однако с начала XIX века они начинают вытесняться: в Яринском - весенними браками, причем уже на рубеже веков, в Бисерове и Снежетке, где посты соблюдались менее строго (см. ниже) - зимними, причем в Снежетке этот процесс шел интенсивнее. В 1850-е годы популярность осенних браков вновь начинает расти, что может быть связано как с улучшением экономического состояния домохозяйств, так и с распространением летних отхожих промыслов среди мужчин.

\footnotetext{
${ }^{4} \mathrm{http}: / /$ www.demoscope.ru/weekly/2020/0883/nauka03.php

${ }^{5}$ https://vgd.ru/m/
} 
Запрет на венчание на Святки на деле соблюдался не всегда. В приходе Снежетка в 1763-1829 гг. зафиксировано 8 таких событий, в Бисерове - 1 и ни одного случая в приходе Яринского.
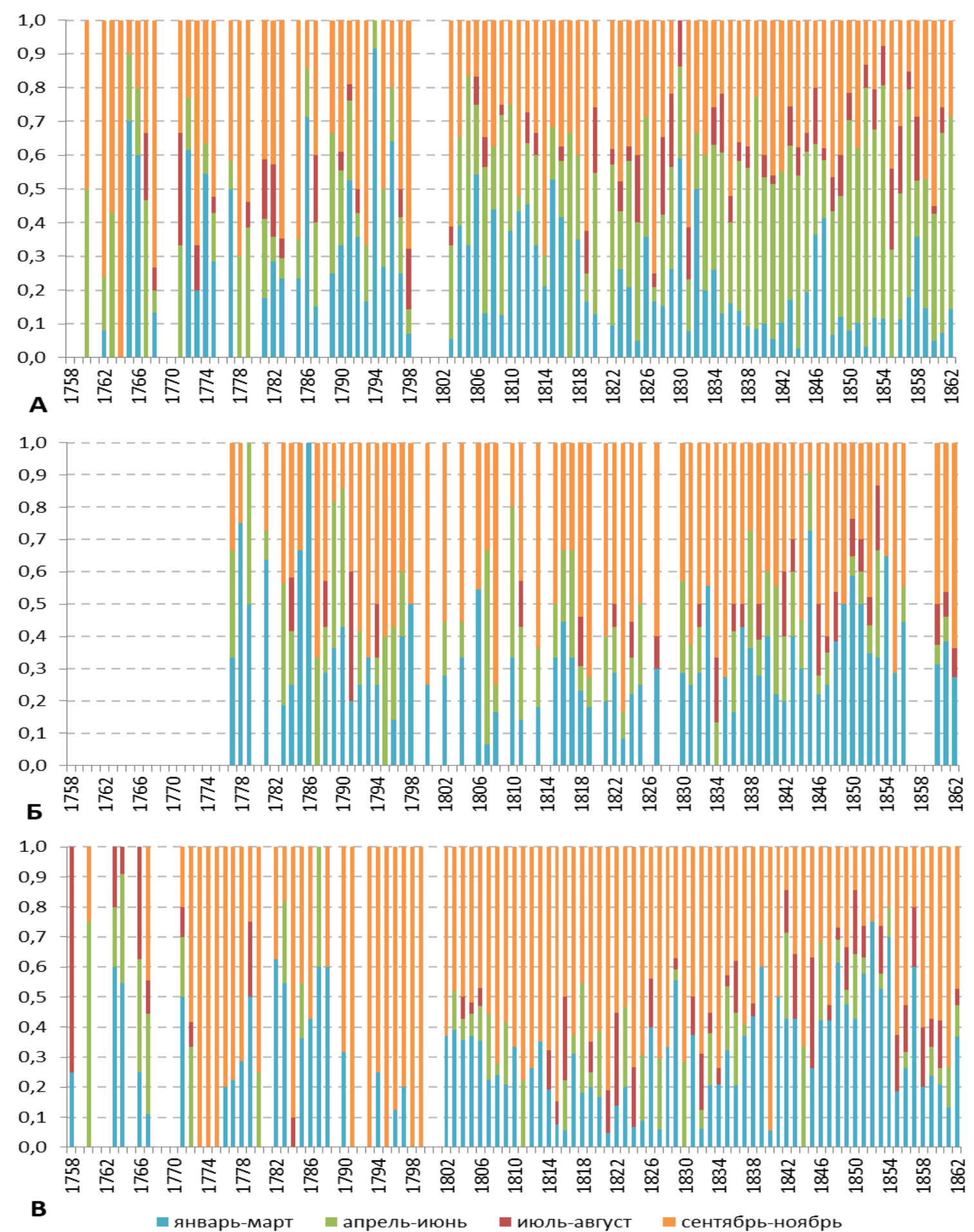

Рисунок 1. Сезонность венчаний в Яринском (А), Бисерове (Б) и Снежетке (В) по годам, доли от 1

Источник: Расчетьл автора. 
Возраст вступления мужчин в первый брак (рисунок 2) в Яринском на протяжении всего рассматриваемого периода был минимально разрешенным. В XVIII веке метрики там фиксировали даже браки достоверно 11-летних юношей, затем по указам минимальный возраст женихов увеличился до 15 лет с 1775 г. и 18 лет с 1830 г. К середине XIX века возраст первобрачных мужчин в Яринском вырос до 19-20 лет. В Снежетке он был уже в XVIII веке значительно больше 18 лет, испытал некоторое снижение в первой трети XIX века, а затем начал быстро расти до примерно 22 лет к началу 1860-х годов. Для Бисерова уже в последних десятилетиях XVIII века обычным возрастом жениха были 20 лет и больше, к середине XIX века он вырос примерно до 24 лет. Аналогичные тенденции увеличения брачного возраста в середине XIX века, правда, до чуть меньших, чем в Бисерове, значений, отмечены в Выхинской вотчине Московского уезда (Avdeev, Troitskaia, Blum 2004).

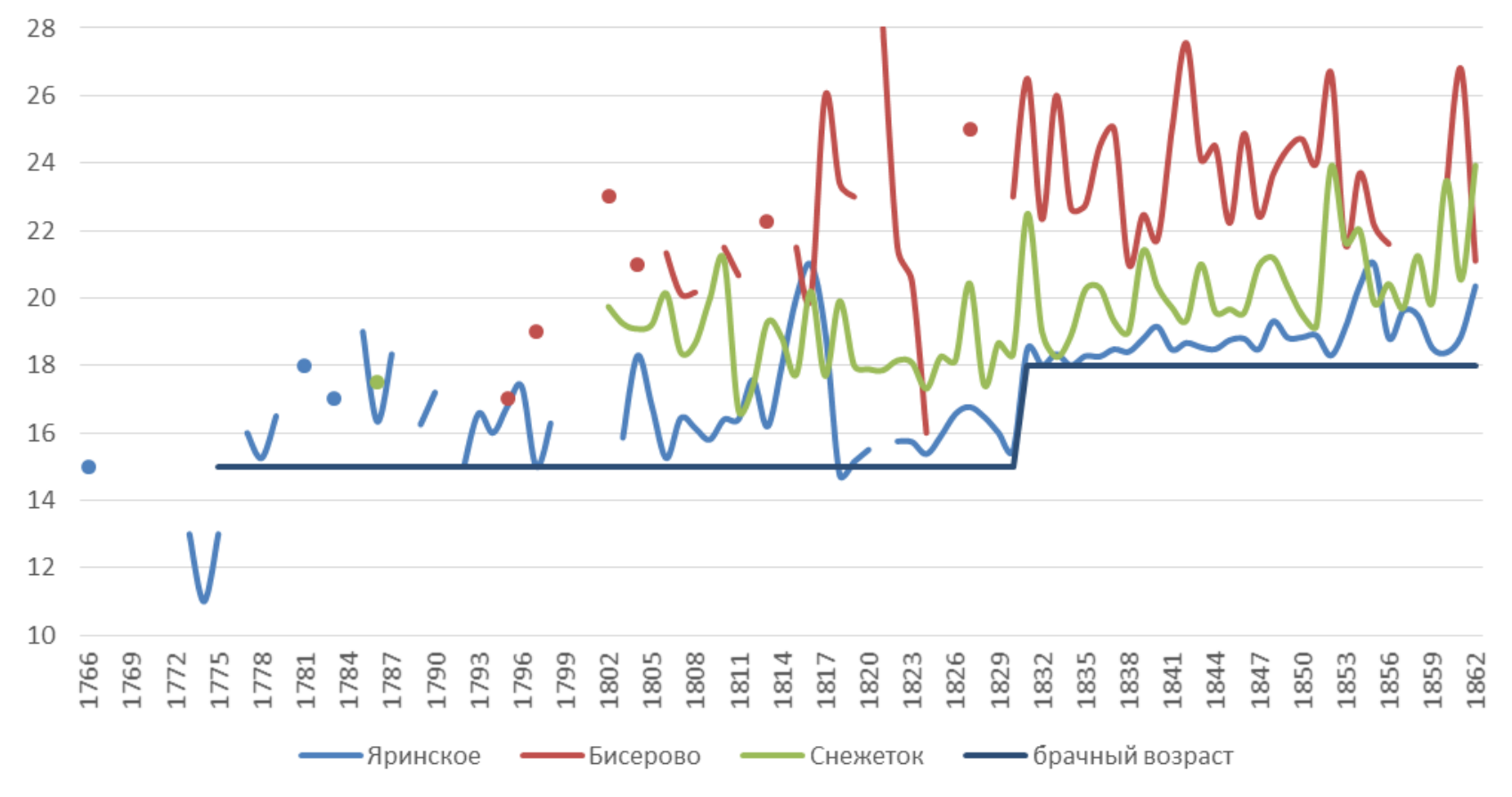

Рисунок 2. Средний возраст вступления мужчин в первый брак и минимальный разрешенный брачный возраст по годам, лет

Источник: Расчеты автора.

Возраст невест (рисунок 3) при первом браке во всех трех приходах был значительно выше минимально разрешенного (13 лет с 1775 г., 16 лет с 1830 г.). В Яринском в XVIII веке он составлял около 17 лет, затем поднявшись до 18-19. Таким же он был в приходе Снежетка. При этом в Бисерове невесты были намного старше - средний возраст составлял 20-22 года, а иногда еще выше. 


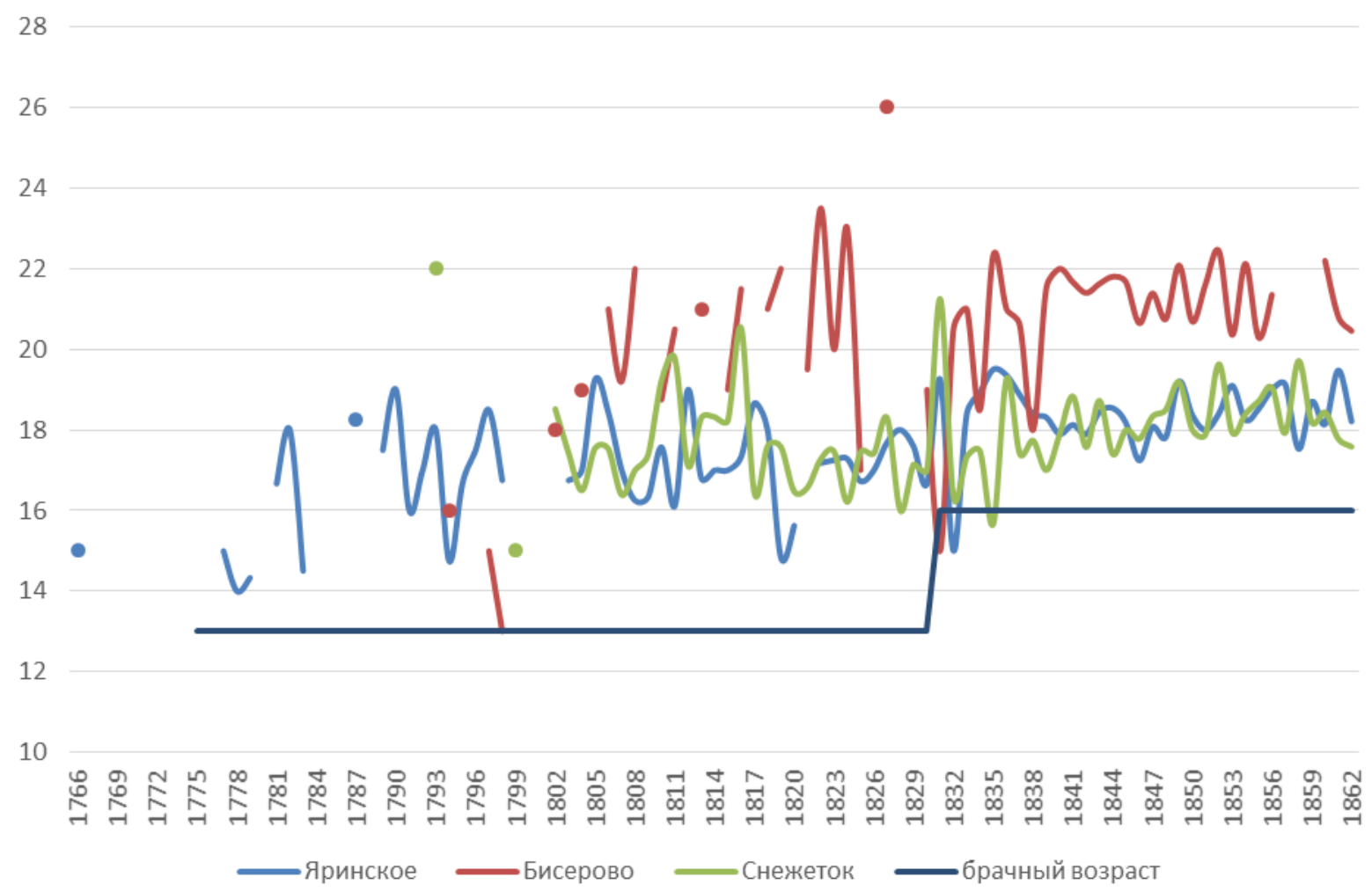

\section{Рисунок 3. Средний возраст вступления женщин в первый брак и минимальный разрешенный брачный возраст по годам, лет}

Источник: Расчеты автора.

Заключение браков с нарушением минимального брачного возраста было крайне редким событием в Яринском и Бисерове (около 5\% браков, почти исключительно из-за малолетства женихов), но обычным явлением в Снежетке, где до половины всех венчанных пар, чей возраст можно установить по метрическим книгам того же прихода, даже в середине XIX века реально не удовлетворяли возрастным требованиям.

Обычная для многопоколенных сельских семей тенденция, когда при первом браке жених был моложе невесты, была ярко выражена в Яринском до 1830 г. (55-60\% браков). С повышением минимального брачного возраста на 3 года это стало редким событием (19\% браков). В Бисерове во 2-ой четверти XIX века женихи были моложе невест при 29\% венчаний. В Снежетке уже в первые десятилетия XIX века подобная ситуация возникала лишь в 14\% супружеств, а во 2-ой четверти века - только в $9 \%$ браков.

Вотчина Подола до отмены крепостного права в 1861 г. была почти исключительно эндогамной, тогда как в вотчине Бисерово на протяжении рассматриваемого периода доля невест из той же вотчины снижалась и к началу 1860-х составляла около $30 \%$ (рисунок 4). В Снежетке невест из-за пределов прихода было несколько меньше - около четверти, и эта доля не менялась. 


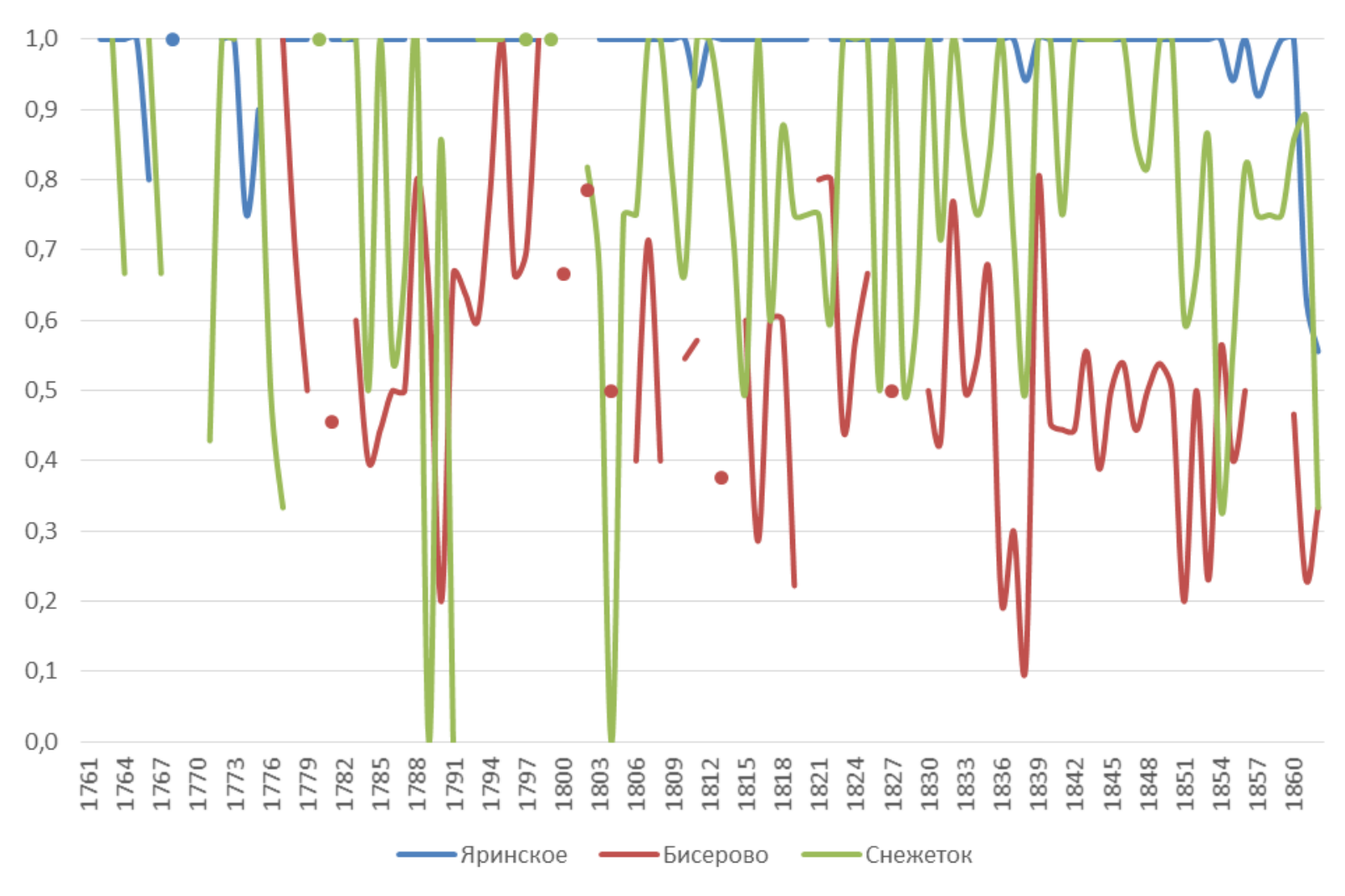

Рисунок 4. Доля невест из той же вотчины и того же прихода по годам, доля от 1

Источник: Расчеты автора.

\section{РОЖДЕНИЯ}

Критерием проверки достоверности статистики рождений может служить отношение числа девочек к числу мальчиков (рисунок 5), которое при естественной рождаемости должно быть около 0,95. Результаты анализа этого показателя позволяют говорить о достоверном учете рождений в Яринском уже в конце 1760-х годов, в Бисерове уже в 1770-е годы, а в Снежетке лишь с начала XIX века, но с явным недоучетом родившихся вплоть до начала 1860 -х годов. В эндогамной вотчине Подола (приход Яринского) уже в 1780-90-е годы число найденных записей о рождении невест составляло $60-70 \%$ от записей о женихах, что говорит об относительно хорошем учете там рождаемости уже в 1760-70-е годы. В Бисерове в 1800-е годы (записи 1780-х) аналогичный показатель близок к 100\%, а в Снежетке даже в 1820-е годы (записи 1800-х) находился на уровне 80\%.

Как было показано в более ранних исследованиях (Авдеев, Блюм, Троицкая 2002; Миронов 2005; Винник 2012а), важным фактором сезонности рождений было соблюдение (или не соблюдение) православных постов. Для всех трех приходов характерны (рисунок 6) общие черты динамики этого показателя: в XVIII веке посты редко соблюдали, в первой четверти XIX века начали соблюдать намного строже, но затем их соблюдение стало постепенно ослабевать. При этом в Яринском посты соблюдали строже уже в XVIII веке, приход отличался повышенным воздержанием вплоть до 1840-х годов, когда его показатели 
стали мало отличаться от двух других. В Снежетке посты соблюдались наименее строго в течение всего рассматриваемого периода.

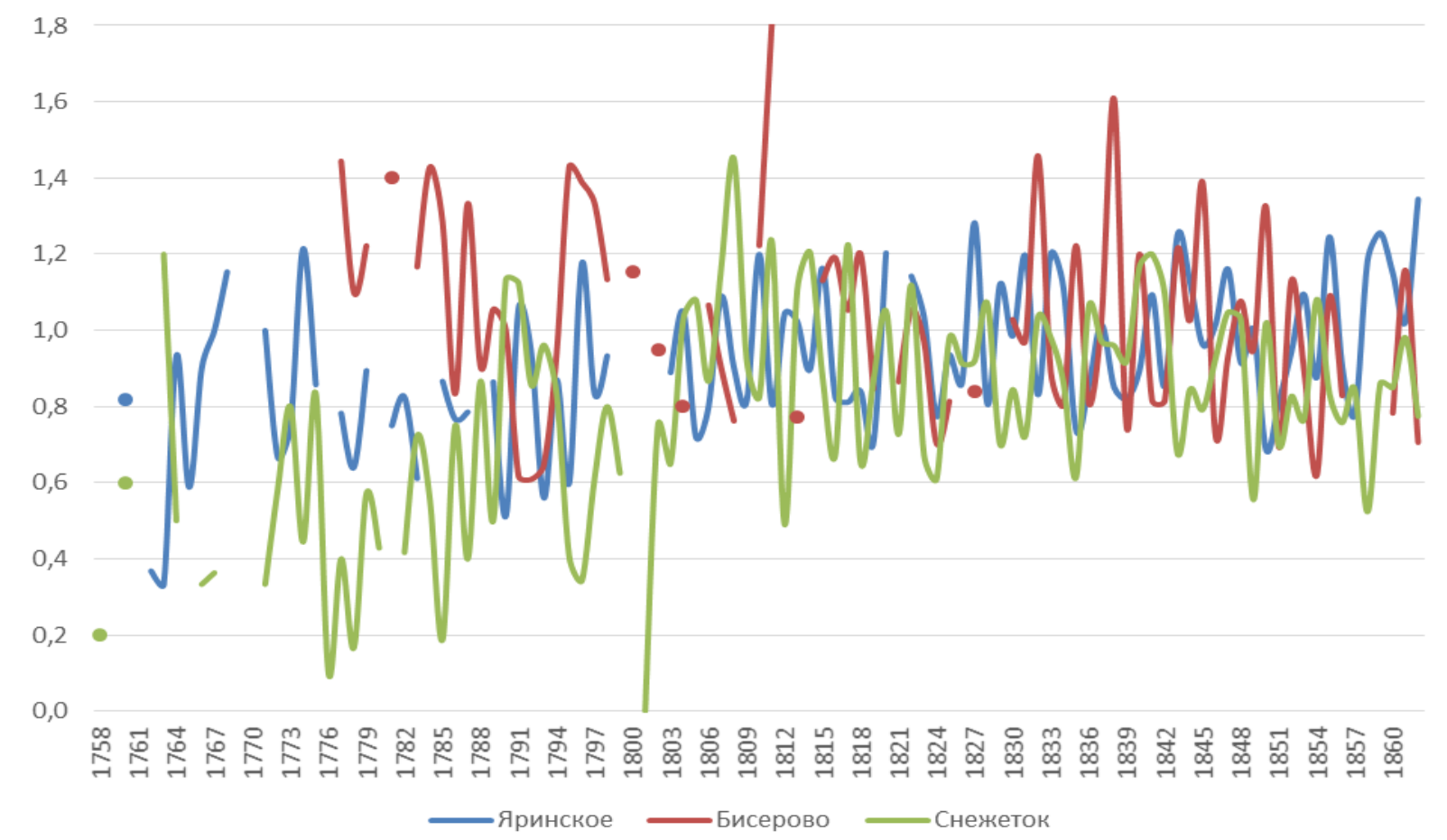

Рисунок 5. Отношение числа учтенных рождений девочек и мальчиков по годам Источник: Расчеты автора.

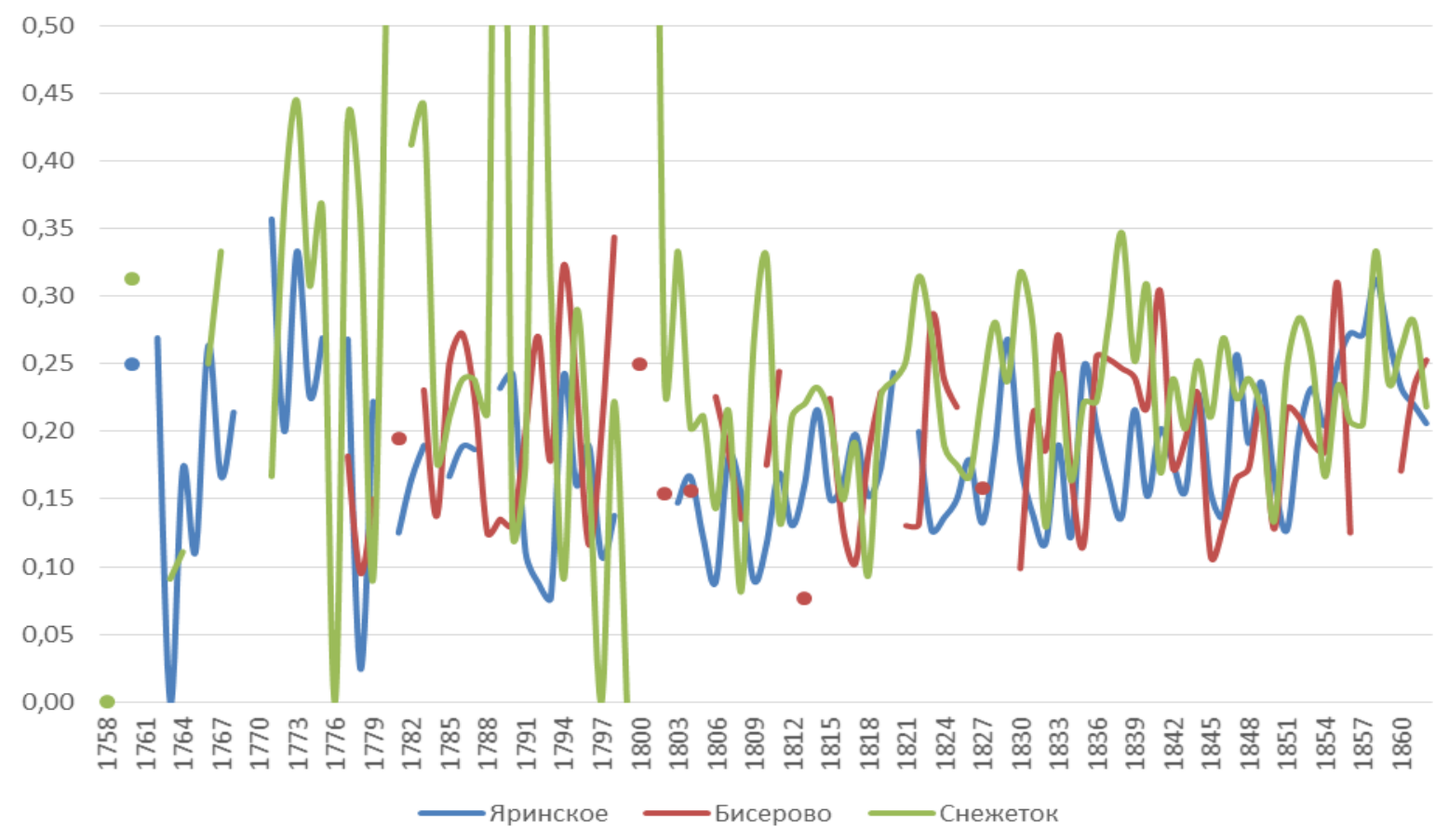

Рисунок 6. Доля рождений в сентябре, декабре и мае (вероятные зачатия в Великий, Рождественский и Успенский посты) по годам, в долях от 1

Источник: Расчеты автора. 
Оценка коэффициентов общей или суммарной рождаемости по данным метрических книг представляет известную проблему, поскольку трудно достоверно оценить возрастную структуру женского населения. Общее представление о динамике рождаемости дает расчет числа рожденных детей по отдельным бракам (рисунок 7). В XVIII веке число детей в семьях в Бисерове и Яринском составляло около 5 (в Бисерове чуть больше). В первой четверти XIX века оно выросло до 6-7 и было больше, чем аналогичный показатель в Снежетке, но затем к началу 1840-х годов начало снижаться до 5 (далее на показатель влияет ограничение ретроспективного периода). При этом в Бисерове число детей было выше, чем в Яринском, а в Яринском выше, чем в Снежетке. Близкие результаты дает рассмотрение среднего числа детей по годам рождения матерей (рисунок 8), но в этом случае Бисерово уступает Яринскому ${ }^{6}$. Досчет числа рождений за годы отсутствия метрических книг Fобщ был произведен по формуле $\mathrm{F}_{\text {общ }}=\mathrm{F}_{\text {изв}} /(1-\mathrm{x})$,

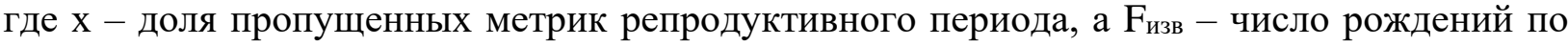
доступным метрикам. Автором рассчитан и популярный в прошлом показатель статистического отношения числа детей к числу браков, который равен 4-5 и соответствует данным для России за начало XIX века (Рашин 1956) ${ }^{7}$.

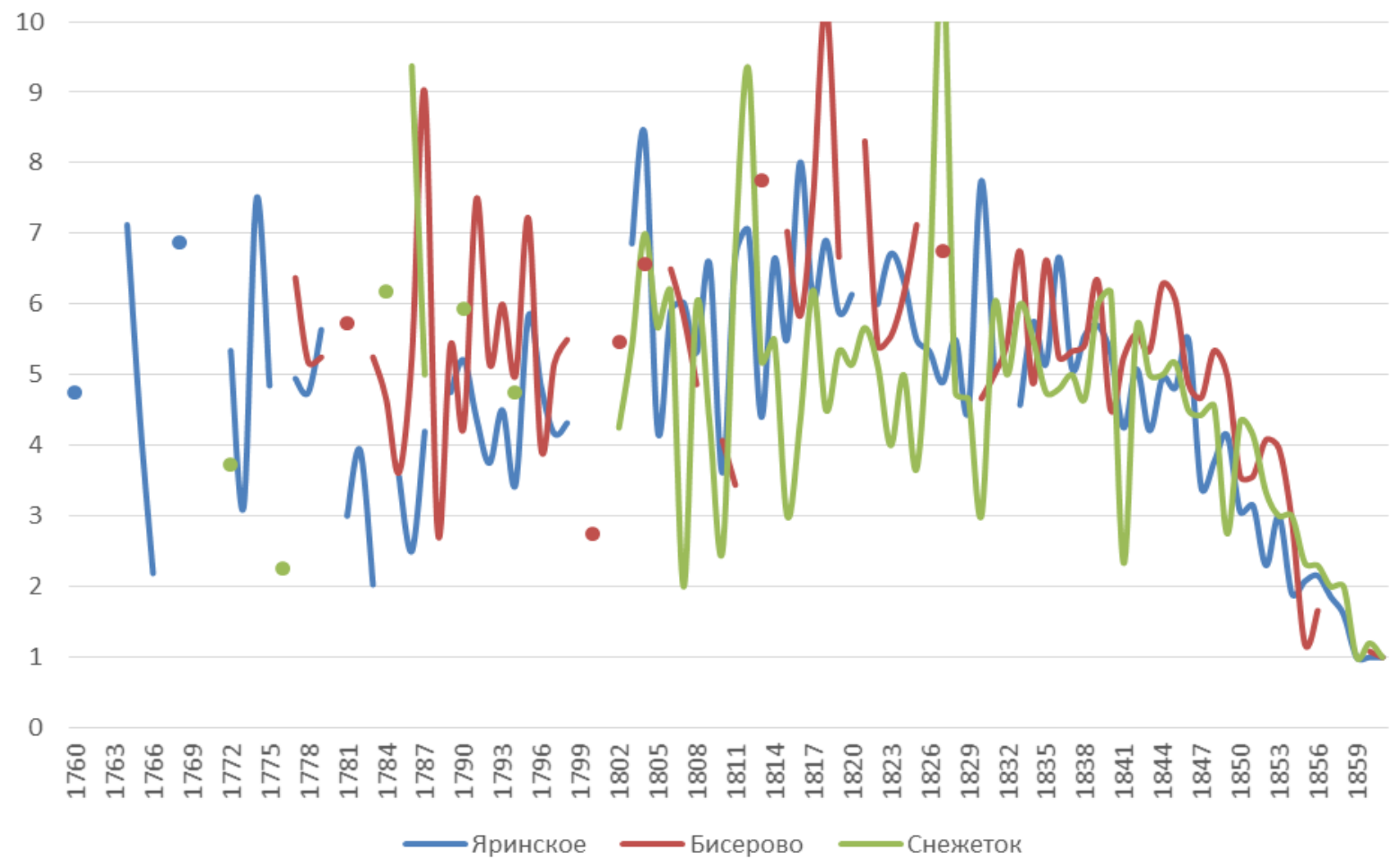

Рисунок 7. Среднее число известных у супругов детей по годам венчания (если дети были) с поправкой на отсутствие части метрических книг, чел.

\footnotetext{
6 Для расчета год рождения должен быть либо взят из метрики, либо вычислен для невест того же прихода. Это сильно сужает выборку и ведет к большей амплитуде значений, особенно, в Снежетке.

7 Этот суррогатный показатель ожидаемо ниже числа рожденных детей, поскольку не учитывает повторные браки, но главное, соотносит рождаемость предшествующих, обычно более малочисленных, поколений, которые могли вступить в брак и 20-30 лет назад, с брачностью нынешних людей молодых возрастов.
} 
Источник: Расчетьл автора.

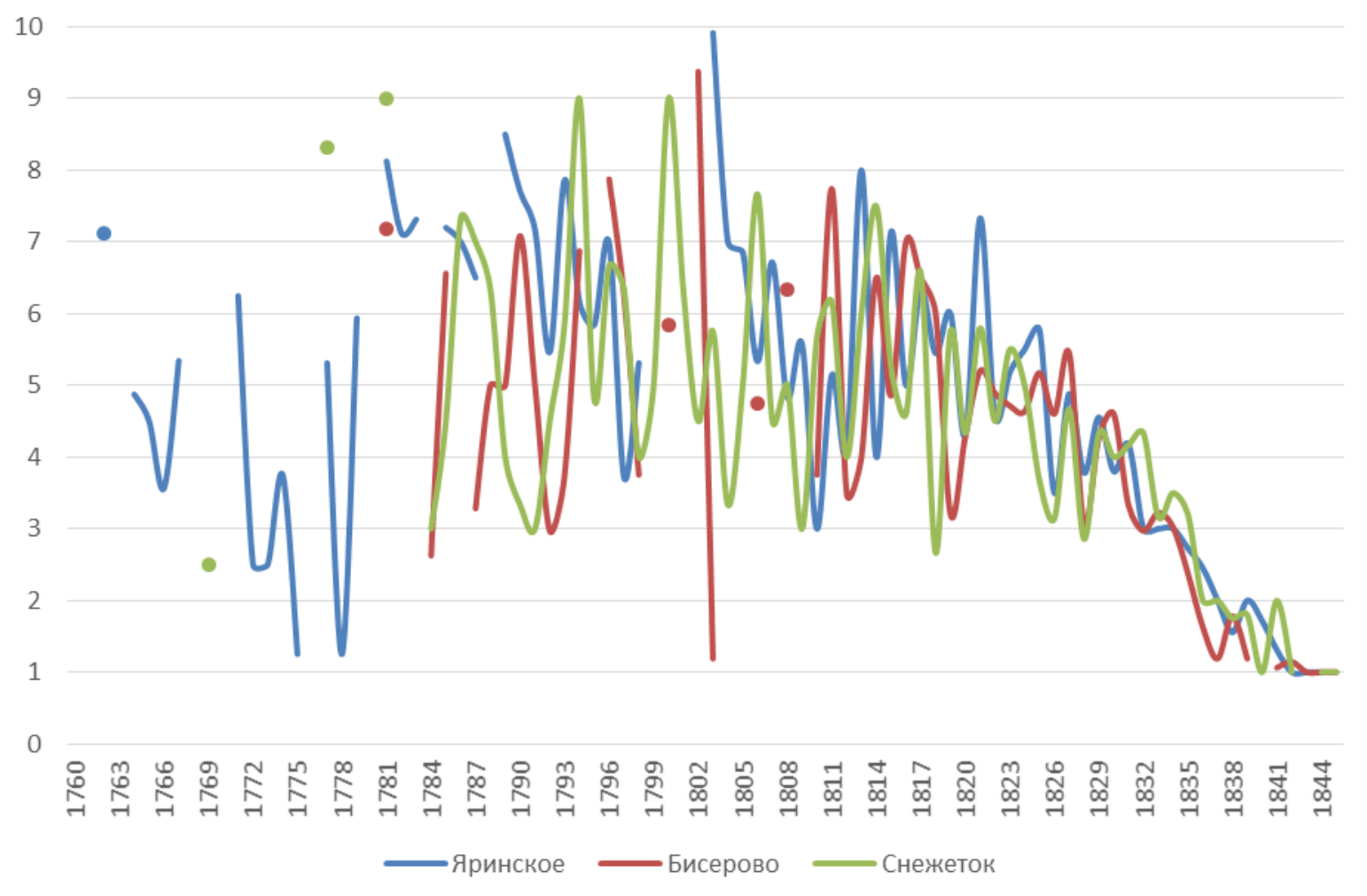

Рисунок 8. Среднее число детей по годам рождения матерей (если дети были), с поправкой на отсутствие части метрических книг, чел.

Источник: Расчеты автора.

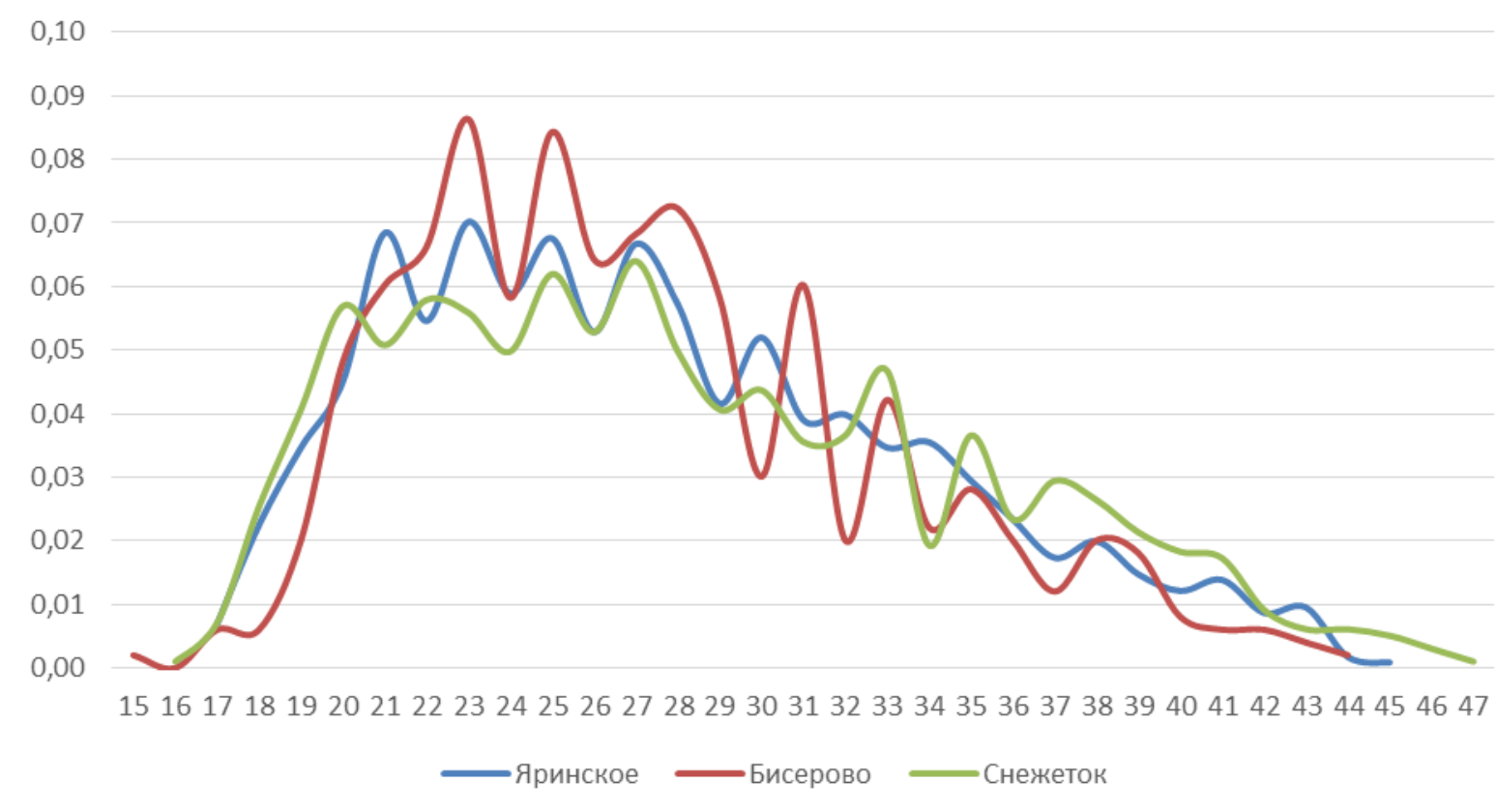

Рисунок 9. Распределение родившихся в 1830-50 гг. по возрасту матери, в долях от 1 Источник: Расчеты автора. 
Структура рождений по возрастам матерей (рисунок 9) для Яринского и Снежетка мало отличается друг от друга, тогда как в Бисерове она выделяется более поздним выходом на высокий уровень из-за более поздних браков, а также очень высокой интенсивностью рождений в возрасте 20-30 лет, на который приходится $70 \%$ всех новорожденных (для сравнения в Яринском - 64\%, в Снежетке - 58\%). При этом доля родившихся у женщин старше 30 лет в Бисерове заметно ниже, чем в других приходах.

Внебрачная рождаемость отмечается метрическими книгами Яринского и Снежетка уже в XVIII веке, но в Бисерове устойчиво появляется только в 1830-е годы. При этом в Снежетке доля внебрачных рождений быстро растет с 1800-х годов, достигает 6-8\% и более в 1810-20-е годы и сохраняется на сравнительно высоком уровне дальше. Исключительно важен анализ структуры внебрачной рождаемости. Если в Яринском вплоть до 1830-х (а в Бисерове и позже) ее «эмитентами» были вынужденно оставшиеся в одиночестве вдовы и солдатки, то в Снежетке уже в 1810-е годы статистически заметно рождение детей у женщин, никогда не состоявших в браке, а к концу 1840-х на них приходилась большая часть внебрачных детей. Для Снежетка характерно и распространение связанной с внебрачной половой жизнью «французской» или «венерической» болезни (сифилис), от которой в 1808-58 гг. в приходе умерли 22 человека.

\section{СмеРти}

Для анализа общего демографического благополучия (или неблагополучия) традиционно используется показатель детской смертности. Его наиболее грубая оценка - отношение числа умерших до 10 лет включительно к числу родившихся в конкретные годы. Его рассмотрение позволяет сделать вывод о существенном учете детской смертности в Бисерове и Яринском уже в 1780-е годы, что в Снежетке происходит только со второй половины 1820-х годов. При этом детская смертность во всех трех приходах устойчиво растет со второй половины 1840-х годов.

За исключением пола ребенка (девочки выживали чаще, что известно и по более поздним данным общероссийской переписи населения (Новосельский 1916)), во всех трех приходах важным фактором младенческой смертности был месяц рождения. Дети, родившиеся в Яринском и Бисерове в мае-июне, а в более южном Снежетке в апреле, рано страдали от летнего всплеска кишечных инфекций и умирали значительно чаще ${ }^{8}$. В Яринском второй пик смертности малышей приходился на декабрь (простуды). Выраженная сезонность младенческой смертности была отмечена и в других исследованиях (Винник 2012а). Минимальная смертность характерна для детей, родившихся в январе-феврале. Важным фактором был и возраст матери, его увеличение с 20-25 до 35-40 лет статистически означало рост детской и младенческой смертности на 10 п.П. во всех трех селах (рисунок 10).

\footnotetext{
${ }^{8}$ Рассматривали только метрические книги 1830-50 гг., где нет пропусков отдельных годов.
} 


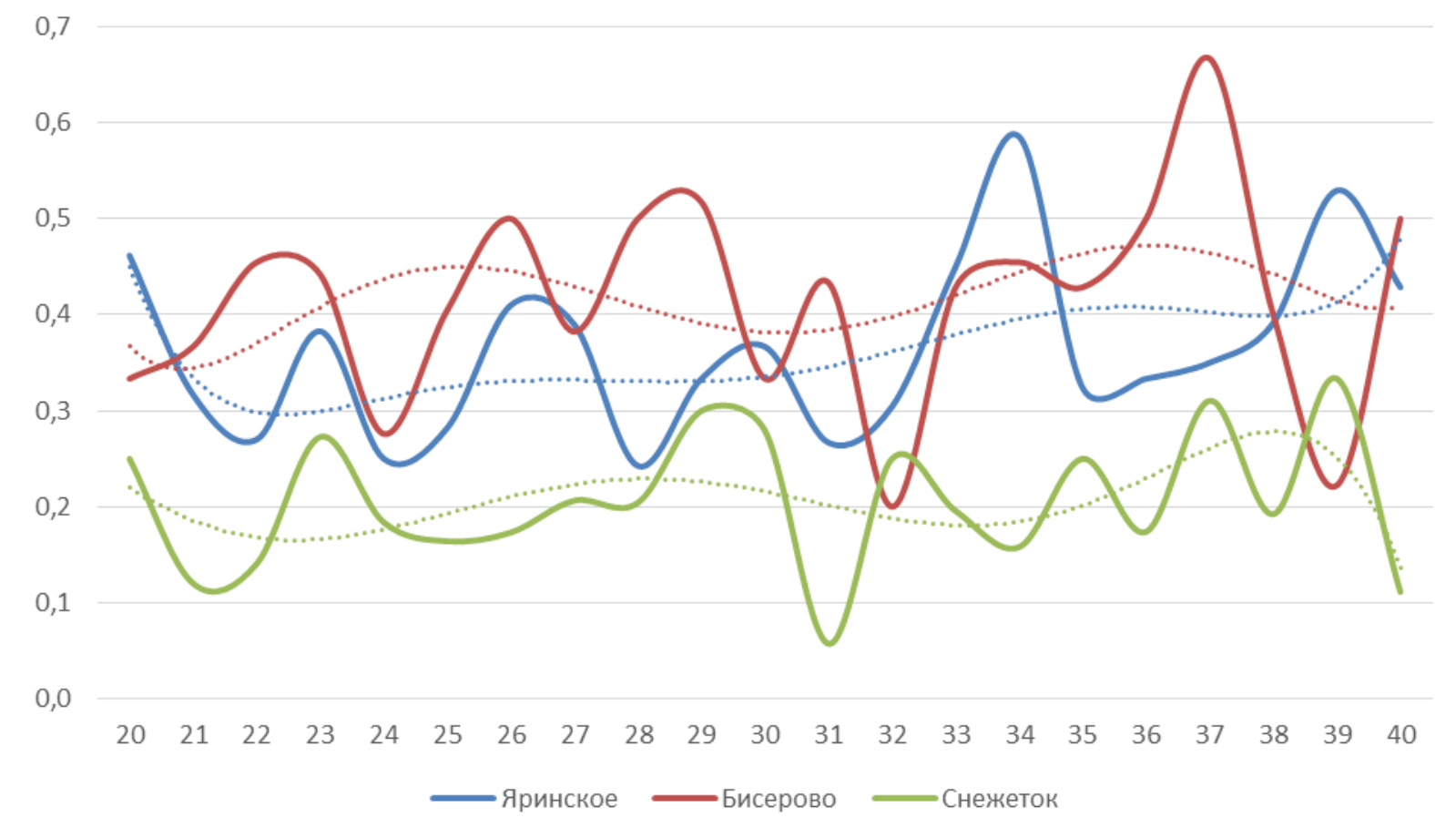

Рисунок 10. Доли учтенных умерших до 10 лет среди родившихся в 1830-50 гг. в зависимости от возраста матери (горизонтальная ось) и их полиномиальные тренды, в долях от 1.

Источник: Расчеты автора.

Гораздо более точная оценка детской смертности при ее неполном учете исследование обратного показателя, дожития до брака (что при любом возрасте венчания означает как минимум дожитие до взрослого возраста). Оценка данного показателя может быть сделана с использованием алгоритмов автоматической обработки данных 9 . В Яринском этот метод позволят оценить дожитие до взрослого возраста как мальчиков, так и девочек (эндогамия), в Бисерове и Снежетке - только мальчиков. В Яринском уже в XVIII веке до брака доживали около половины мальчиков, но в 1810-е годы этот показатель падает до трети, в дальнейшем возвращается на прежний уровень, а с конца 1820-х годов уверенно снижается (рисунок 11, отдельно выделена младенческая смертность до 3 лет включительно). В Бисерове до свадьбы доживали примерно треть мальчиков, причем с течением времени эта цифра менялась незначительно. В Снежетке метод осложняется явным недоучетом браков в метрических книгах, но дает в XVIII веке значение 40\%, которое к началу 1830-х годов плавно снижается до 20\%. Дожитие до брака девочек в Яринском в XVIII веке было на уровне 50-60\%, снизившись по аналогичной мужчинам траектории к началу 1840-х годов примерно на 10 п.п.

\footnotetext{
${ }^{9}$ В исследовании это сделано с помощью формул в Excel, которые искали число новорожденных в части 1 метрики подходящего возраста, места рождения, имени и отчества, по которым ранее не были найдены записи о смерти в детстве в части 3 и еще нет пометки о браке. Найденные записи автор проверял вручную на соответствие информации о родителях новобрачных, если такая была, с одновременной проверкой по ревизиям для исключения тезок, лишь при однозначном соответствии ставил пометку о браке.
} 

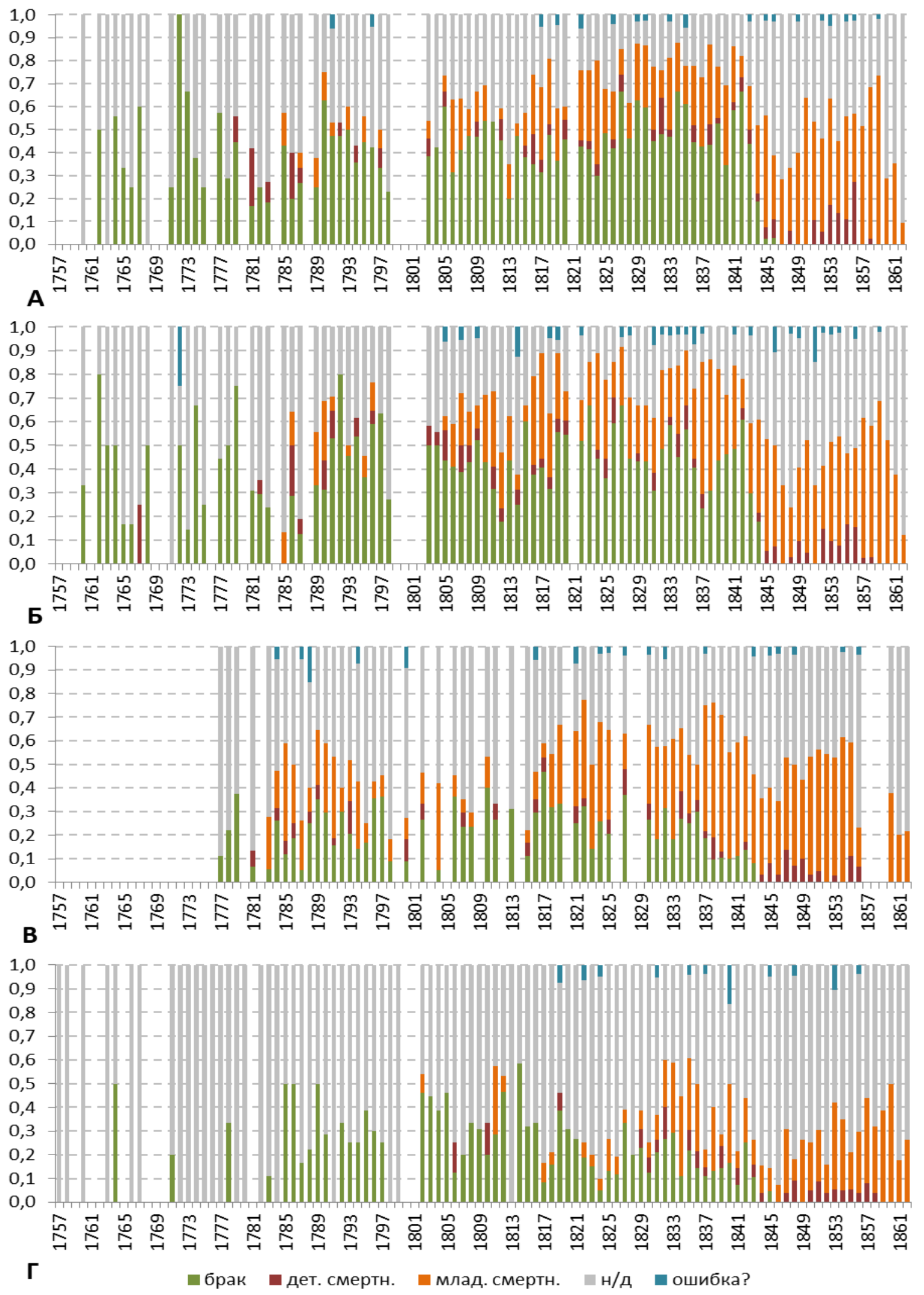

Рисунок 11. Судьба девочек Яринского (А), мальчиков Яринского (Б), Бисерова (В) и Снежетка (Г) по данным метрических книг по годам, доли от 1

Источник: Расчеты автора. 
Оценить ожидаемую продолжительность жизни традиционными статистическими методами сложно из-за низкой достоверности данных о половозрастной структуре населения $^{10}$ и инфляции возрастов пожилых умерших. В качестве замены рассчитан медианный возраст смерти умерших старше 15 лет. Метрические книги Яринского фиксируют этот показатель как очень низкий в 1760-е годы, аналогичные оценки (около 50 лет) дают и редкие данные Снежетка (рисунок 12). В конце XVIII века во всех трех приходах показатель составляет около 60 лет, однако дальше происходит его общее и выраженное снижение до 50 лет к середине 1810-х годов, затем - возврат на уровень 60 и новое устойчивое снижение до 50, а в отдельные годы и до 40 лет, начиная с 1830-х. При этом в Снежетке эти показатели самые низкие на протяжении всего рассматриваемого периода, тогда как в Яринском они несколько выше, чем в Бисерове. Выраженный географический тренд роста смертности населения по мере сдвига на юго-восток от Центральной России был отмечен еще в классических работах по исторической демографии (Рашин 1956).

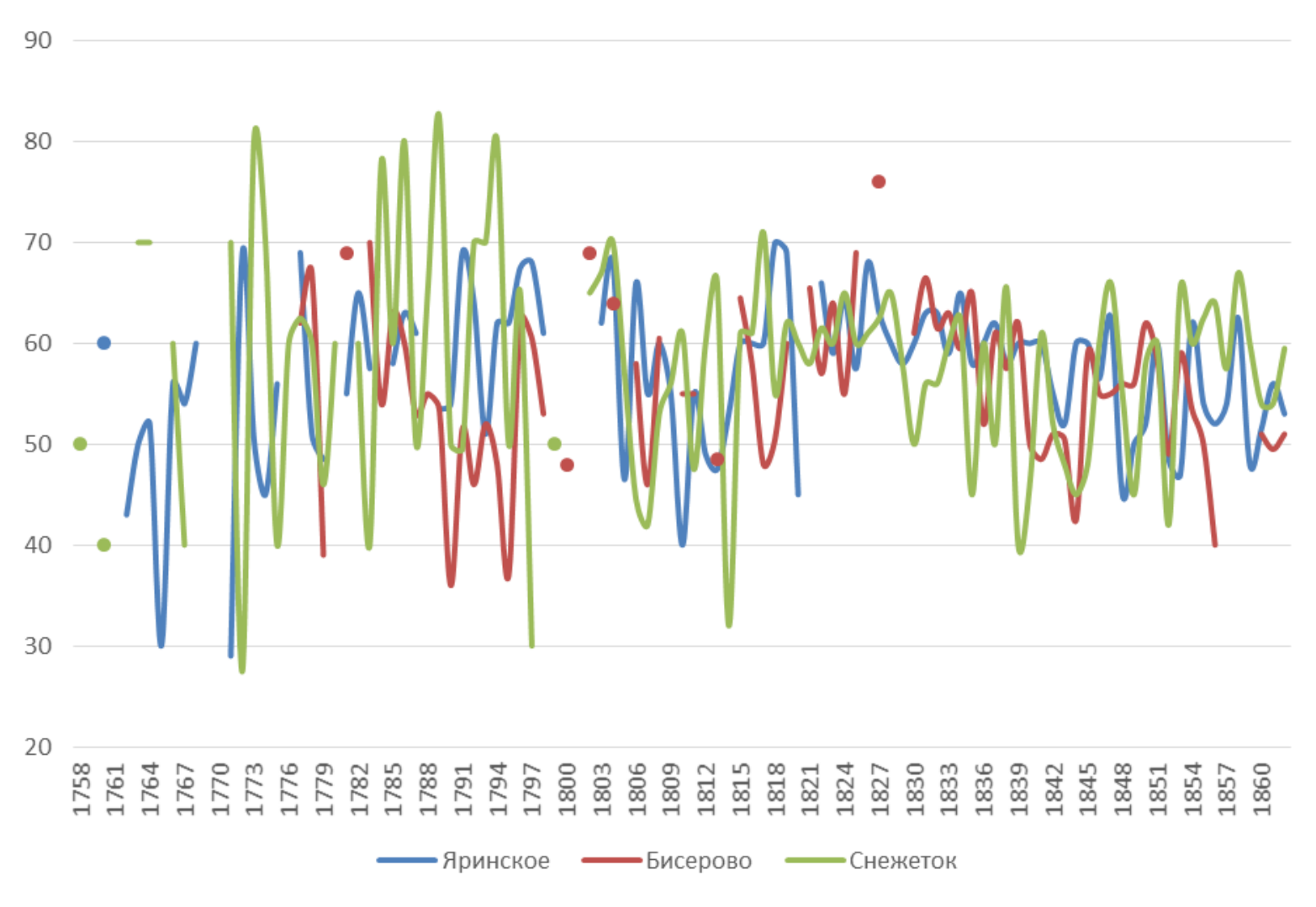

Рисунок 12. Медианный возраст смерти умерших в 15 лет и старше по годам, лет

Источник: Расчеты автора.

Другой измеритель социального неблагополучия - смертность от внешних причин, которая отмечалась и в XVIII веке, но устойчивым явлением в Снежетке стала с 1810-х годов, в Яринском с 1820-х, а в Бисерове - только с 1830-х, однако быстро превзошла

${ }^{10}$ К примеру, индекс Уиппла для женщин вотчины Бисерова по ревизии 1816 г. (в предыдущей ревизии 1811 г. женщин не переписывали, поэтому данные о возрасте на нее не опираются) равен 226,9, т. е. почти у половины возраст округлен до чисел, кратных 5. При этом половина невест из других приходов. 
там показатели двух других приходов. В целом во всех трех приходах на внешние причины к середине XIX века приходилось 2-3\% смертей детей и взрослых. Показательным было разное отношение к алкогольной смертности - если в Яринском за диагнозом «пьянство» (2 случая) следовало «зарыт в болоте без отпевания», то в Бисерове скончавшихся от горячительных напитков (5 случаев) погребали на приходском кладбище в общем порядке.

Ярким явлением метрических книг Снежетка была инфляция возраста смерти пожилых людей, которая не характерна для двух других приходов. При этом если в заявленных возрастах от 60 до 80 лет инфляция линейная (возраст завышается в среднем на 10 лет), то при заявленном возрасте старше 80 инфляция становится экспоненциальной. В действительности в Снежетке не выявлено ни одного человека, чей подтвержденный ранними документами возраст смерти превысил бы 85 лет, исключительно редкими были и смерти людей старше 80 лет.

\section{СОЦИАЛЬНО-ДЕМОГРАФИЧЕСКИЕ ПРОФИЛИ}

Выполненный анализ демографических показателей позволяет с некоторой условностью сформировать социально-демографические профили населения каждого прихода.

Приход Яринского отличался крайне ранним, на пороге минимального возраста, вступлением в брак мужского населения. В Яринском относительно строго соблюдались как установления брачного законодательства, так и православные посты. Для прихода характерна высокая рождаемость, распределенная на весь возрастной интервал репродуктивного возраста, что дает ее относительно низкую интенсивность в расчете на один год возраста. Выживаемость детей в семьях была достаточно высокой, также относительно высокой была и продолжительность жизни взрослого населения. В результате темпы роста населения в приходе были устойчиво выше, чем в двух других. Характерна низкая внебрачная рождаемость у еще не состоявших в браке женщин, а также низкая смертность от внешних причин. Объяснение этих явлений может быть связано с культурными особенностями прихода, тесными внутренними социальными связями, эндогамией, организацией жизни в соответствии с установлениями Церкви.

Приход Снежетка отличается, прежде всего, крайне небрежным ведением метрических книг, в том числе в части, касающейся браков. О приоритете традиций и воли жителей над внешними правилами говорит частое нарушение минимального брачного возраста, а также запрета венчания в Святки и очень слабое соблюдение постов. Семьи Снежетка были патриархальными (о чем говорит устойчивое наследование фамилий, а также завышение возраста пожилым ${ }^{11}$ ), но редко были многопоколенными (сравнительно позднее вступление в брак мужчин, исключительная редкость браков, где невеста старше), социальные связи в приходе были рыхлыми, но выходили далеко за его пределы. Местное общество терпимо относилось к внебрачной рождаемости даже у незамужних женщин.

${ }^{11}$ В патриархальном клановом обществе чем старше человек, тем больше у него потомков, для которых он является хоты бы номинальным главой, а значит, его социальный статус выше. 
В приходе была сравнительно высокая рождаемость, но и повышенная смертность как среди детей, так и взрослых.

Приход Бисерова отличается выраженной экзогамией, очень поздним вступлением в брак как мужского, так и женского населения, относительно строгим соблюдением постов и низкой внебрачной рождаемостью на фоне большой доли незамужних женщин. Также Бисерово выделяется очень высокой смертностью от внешних причин и крайне низкой выживаемостью детей, несмотря на высокую интенсивность рождений. Даже в XIX веке фамилии у крестьян были неустойчивыми, что говорит о редкости многопоколенных семей. Отдельного внимания заслуживает анализ высокой младенческой смертности в приходе Бисерова. Вероятное ее объяснение связано с высокой интенсивностью рождений, которая была призвана «компенсировать» позднее вступление в брак и саму высокую смертность ранее рожденных детей, а также с тенденцией к экзогамии, которая означала отсутствие у матерей социальных связей с кровными родственниками внутри прихода.

\section{ЗАКЛЮЧЕНИЕ}

Анализ массива метрических книг трех приходов в разных частях Европейской России за столетний период позволяет сформировать представление об общей динамике демографических показателей в эту эпоху (благополучие в 1790-е и 1820-е, кризисы в 176080-е и 1830-50-е годы) и об их пространственных различиях (лучшая ситуация в Нечерноземье, хуже в Черноземье и пригородной зоне Москвы). Метрические книги уже XVIII века могут считаться источником достаточно точной ежегодной демографической информации, подобной той, что сейчас собирается органами ЗАГС. Процесс расшифровки метрических книг и их обработки трудоемок, однако продолжение и интеграция подобных исследований поможет сформировать более подробную картину демографического развития России в доиндустриальный период. Уже выполненные исследования показывают, что на демографические показатели влияли социокультурные особенности отдельных территорий, а устойчивое откладывание вступления в брак и снижение рождаемости происходили задолго до действия традиционных факторов теории демографического перехода, в частности, на фоне не снижения, как предполагает теория, а роста смертности детского и взрослого населения.

\section{БЛАГОДАРНОСТИ}

Автор благодарит коллектив Института демографии им. А.Г. Вишневского ВШЭ за возможность поделиться полученными выводами в рамках научного семинара. Отдельно благодарит организатора и ведущего семинара Валерия Юмагузина, сотрудников ВШЭ Владимира Козлова, Марию Винник и Дениса Иванова за живой интерес к теме, поддержку и мотивацию научной обработки первичных источников информации. Автор выражает признательность анонимным рецензентам публикации за ценные замечания и рекомендации, глубокое погружение в проблематику статьи. 


\section{ЛИТЕРАТУРА}

Авдеев А., Блюм А., Троицкая И. (2002). Сезонный фактор в демографии российского крестьянства первой половины XIX века: брачность, рождаемость, младенческая смертность. Российский демографический журнал, 1, 35. URL: http://www.demoscope.ru/weekly/2003/0135/analit04.php

Винник М.В. (2012b). Метрические книги как источник по истории населения России. Демоскоп Weekly, 535-536. URL: http://www.demoscope.ru/weekly/2012/0535/analit012.php

Винник М.В. (2012а). Сезонность демографических процессов (на примере метрических книг Покровского прихода г. Барнаул, 1877-1886 гг.). В М.Б. Денисенко (Ред.), Демографические аспекты соииально-экономического развития. (Вып. 22., Гл. 10., cc. 251-267). М.: MAKC Пресc. URL:

https://publications.hse.ru/mirror/pubs/share/folder/bzom5qu80v/direct/77847147.pdf

Владимиров В.Н., Сарафанов Д.Е., Щетинина А.С. (2016). «Новая историческая демография» в России: эволюция или скачок в развитии? Известия Уральского федерального университета. Сер. 2: Гуманитарные науки, 18, 3(154), 29-53. DOI: https://doi.org/10.15826/izv2.2016.18.3.042

Владимиров В.Н., Сарафанов Д.Е., Щетинина А.С. (2019). Традиционная и новая историческая демография: взгляд специалистов. Вестник Томского государственного университета, 443, 99-105. DOI:https://doi.org/10.17223/15617793/443/13

Миронов Б.Н. (1998). О достоверности метрических ведомостей - важнейшего источника по исторической демографии России XVIII - начала XX в. В Россия в XIX - XX вв.: сборник статей к 70-летию со дня рождения Рафаила Шоломовича Ганелина (сс. 41). СПб.: Дмитрий Буланин.

Миронов Б.Н. (2005). Можно ли увидеть всю Россию из Малых Пупков? В Круг идей: алгоритмы и технологии исторической информации: Труды IX конференции Ассочиаџии «История и компьютер» (сс. 528-543). Барнаул: АлтГУ.

Новосельский С.А. (1916). Смертность и продолжительность жизни в России. Демоскоп Weekly. URL: http://www.demoscope.ru/weekly/knigi/novoselskij/novoselskij.html

Рашин А.Г. (1956). Население России за 100 лет (1811-1913 г2.). Демоскоn Weekly. URL: http://www.demoscope.ru/weekly/knigi/rashyn/rashyn.html

Рязанов В., Денисенко К. (2019). «Черные ящики» русской истории. Эксперт, 8, 59-62. URL: https://expert.ru/expert/2019/08/chernyie-yaschiki-russkoj-istorii/

Avdeev A., Troitskaia I., Blum A. (2004). Peasant marriage in nineteenth-century Russia. Population, 59(6), 721-764. DOI: https://doi.org/10.2307/3654894 


\title{
PATTERNS OF DEMOGRAPHIC PROCESSES IN \\ EUROPEAN RUSSIA IN THE XVIII-XIX CENTURIES: \\ EXPERIENCE OF ANALYZING THE REGISTERS OF THREE \\ ORTHODOX PARISHES
}

\section{VLAS RYAZANOV}

\begin{abstract}
The article examines the registers of three Orthodox rural parishes in geographically different parts of European Russia (35 thousand records of birth, marriage and death) as a source of information on the demography of the country in the mid-18th - mid-19th centuries. The results of processing this data provide an estimate of the overall dynamics of the social and economic well-being of the population during a period when years of improvement of all demographic indicators were interrupted by crises of varying length and severity. These processes had uneven effects on different territories. The parish in the non-Chernozem zone outside the Moscow suburbs showed the best dynamics for the period, while the figures of the Chernozem parish were persistently lowered by high mortality among both children and adults and the Moscow region parish was characterized by later marriage. Since all three parishes represent the rural Russian Orthodox population, these differences can be explained by other socio-cultural characteristics and specific features of these areas.
\end{abstract}

Key words: Russia, historical demography of the 18th and 19th centuries, nuptiality, fertility, mortality, parish registers.

Vlas RYAZANOv (vlas.ryazanov@gmail.com), INSTITUTE of ECONOMICS OF THE RUSSIAN ACADEMY OF SCIENCES, RUSSIA.

DATE RECEIVED : JUNE 2021.

\section{REFERENCES}

Avdeev A., Blum A., Troitskaia I. (2002). Sezonnyy faktor v demografii rossiyskogo krest'yanstva pervoy poloviny 19 veka: brachnost', rozhdayemost', mladencheskaya smertnost' [Seasonal factor of demographics of Russian peasants of first half of $19^{\text {th }}$ century: marriages, births, infant mortality]. Rossiyskiy demograficheskiy zhurnal [Russian Demographic Journal],1, 35. (In Russ.). URL: http://www.demoscope.ru/weekly/2003/0135/analit04.php

Vinnik M.V. (2012b). Metricheskiye knigi kak istochnik po istorii naseleniya Rossii [Parish registers as a source of history of population of Russia]. Demoscope Weekly, 535-536. (In Russ.). URL: http://www.demoscope.ru/weekly/2012/0535/analit012.php

Vinnik M.V. (2012a). Sezonnost' demograficheskikh protsessov (na primere metricheskikh knig Pokrovskogo prikhoda g. Barnaul, 1877-1886 gg.) [Seasonality of demographic processes (on example of registers of Intercession parish of Barnaul city, 1877-1886]. In M.B. Denisenko (Ed.), Demograficheskiye aspekty sotsial'no-ekonomicheskogo razvitiya [Demographic features of social and economic development] (Is. 22, Ch. 10, pp. 251-267). Moscow: MAKS Press. (In Russ.). URL: https://publications.hse.ru/mirror/pubs/share/folder/bzom5qu80v/direct/77847147.pdf

Vladimirov V.N., Sarafanov D.E., Shchetinina A.S. (2016). «Novaya istoricheskaya demografiya» v Rossii: evolyutsiya ili skachok v razvitii? [New historical demography in 
Russia: evolution or leap in development?]. Izvestiya Ural'skogo federal'nogo universiteta, Ser. 2: Gumanitarnyye nauki [Ural Federal University Bulletin. Series 2: Humanities], 18, 3(154), 29-53. (In Russ.). DOI: https://doi.org/10.15826/izv2.2016.18.3.042

Vladimirov V.N., Sarafanov D.E., Shchetinina A.S. (2019). Traditsionnaya i novaya istoricheskaya demografiya: vzglyad spetsialistov [Traditional and new historical demography: professional look]. Vestnik Tomskogo gosudarstvennogo universiteta [Tomsk State University Journal], 443, 99-105. (In Russ.). DOI: https://doi.org/10.17223/15617793/443/13

Mironov B.N. (1998). O dostovernosti metricheskikh vedomostey - vazhneyshego istochnika po istoricheskoy demografii Rossii XVIII - nachala XX v. [About the reliability of parish registers - most important source of historical demography of Russia of $18^{\text {th }}$ - early $20^{\text {th }}$ centuries]. In Rossiya v XIX - XX vv.: sbornik statey $k$ 70-letiyu so dnya rozhdeniya Rafaila Sholomovicha Ganelina [Russia in $19^{\text {th }}-20^{\text {th }}$ centuries: collected papers to the $70^{\text {th }}$ anniversary of R.S. Ganelin birth] (pp. 41). SPb.: Dmitriy Bulanin. (In Russ.).

Mironov B.N. (2005). Mozhno li uvidet' vsyu Rossiyu iz Malykh Pupkov? [Is it possible to have a look at entire Russia from Malyye Pupki?]. In Krug idey: algoritmy i tekhnologii istoricheskoy informatsii: Trudy IX konferentsii Assotsiatsii «Istoriya i komp'yuter» [Circle of ideas: algorithms and technologies of historical data: Papers of $9^{\text {th }}$ Conference of Association "History and a computer"] (pp. 528-543). Barnaul: AltGU. (In Russ.).

Novosel'skiy S.A. (1916). Smertnost' i prodolzhitel'nost' zhizni v Rossii [Mortality and life expectancy in Russia]. Demoscope Weekly. (In Russ.). URL: http://www.demoscope.ru/weekly/knigi/novoselskij/novoselskij.html

Rashin A.G. (1956). Naseleniye Rossii za 100 let (1811-1913 gg.) [Population of Russia in 100 years (1811-1913)]. Demoscope Weekly. (In Russ.). URL: http://www.demoscope.ru/weekly/knigi/rashyn/rashyn.html

Ryazanov V., Denisenko K. (2019). «Chernyye yashchiki» russkoy istorii ["Black boxes” of Russian history]. Expert, 8, 59-62. (In Russ.). URL: https://expert.ru/expert/2019/08/chernyie-yaschiki-russkoj-istorii/

Avdeev A., Troitskaia I., Blum A. (2004) Peasant marriage in nineteenth-century Russia. Population, 59(6), 721-764 DOI: https://doi.org/10.2307/3654894 
Приложение. Демографические показатели приходов и опорных вотчин, агрегированные по десятилетиям

\begin{tabular}{|c|c|c|c|c|c|c|c|c|c|c|c|c|}
\hline Показатель & Село & 1760-e & 1770-e & 1780-e & 1790-e & 1800-e & 1810-e & 1820-e & 1830-e & 1840-e & 1850-e & 1860-e \\
\hline \multirow{3}{*}{$\begin{array}{l}\text { Средний возраст жениха } \\
\text { (первый брак), лет }\end{array}$} & Яринское & 15,0 & 14,5 & 16,1 & 15,2 & 16,4 & 17,5 & 17,9 & 19,4 & 21,0 & 21,8 & 20,3 \\
\hline & Бисерово & & & & 19,0 & 20,9 & 22,9 & 22,2 & 24,6 & 25,5 & 25,2 & 25,4 \\
\hline & Снежеток & & & 17,5 & & 21,4 & 20,5 & 19,0 & 19,7 & 21,2 & 22,0 & 22,5 \\
\hline \multirow{3}{*}{$\begin{array}{l}\text { Средний возраст невесты } \\
\text { (первый брак), лет }\end{array}$} & Яринское & 15,0 & 14,5 & 17,3 & 16,9 & 17,1 & 16,9 & 18,2 & 19,1 & 18,5 & 19,1 & 18,7 \\
\hline & Бисерово & & & & 14,7 & 20,0 & 20,5 & 22,0 & 20,9 & 22,4 & 22,3 & 20,9 \\
\hline & Снежеток & & & & 18,5 & 18,4 & 18,6 & 16,9 & 17,8 & 18,1 & 19,5 & 18,9 \\
\hline \multirow{3}{*}{ Зачатия в посты, \% } & Яринское & 19,9 & 21,7 & 17,9 & 14,7 & 13,6 & 16,3 & 18,1 & 17,2 & 18,9 & 23,3 & 22,0 \\
\hline & Бисерово & & 14,3 & 19,5 & 21,1 & 17,9 & 17,5 & 19,3 & 20,6 & 19,0 & 19,6 & 21,9 \\
\hline & Снежеток & 23,8 & 28,0 & 32,5 & 20,5 & 22,5 & 19,8 & 23,2 & 24,5 & 23,1 & 22,7 & 25,3 \\
\hline \multirow{3}{*}{$\begin{array}{l}\text { Рождения детей, } \\
\text { зачатых вне брака, \% }\end{array}$} & Яринское & 0,0 & 2,1 & 1,9 & 2,0 & 2,1 & 3,8 & 2,0 & 1,8 & 2,2 & 2,8 & 2,2 \\
\hline & Бисерово & & 0,0 & 0,0 & 0,0 & 0,9 & 0,0 & 1,0 & 0,7 & 2,4 & 1,8 & 1,2 \\
\hline & Снежеток & 0,0 & 1,9 & 0,0 & 0,4 & 2,5 & 4,8 & 6,2 & 5,1 & 3,8 & 5,9 & 3,7 \\
\hline \multirow{3}{*}{$\begin{array}{l}\text { Рождений на брак (если были, без } \\
\text { досчета, по годам венчания), чел. }\end{array}$} & Яринское & 3,83 & 4,10 & 3,19 & 3,62 & 6,04 & 5,90 & 5,66 & 5,71 & 4,49 & 2,26 & 1,00 \\
\hline & Бисерово & & 4,91 & 4,72 & 4,13 & 4,42 & 5,27 & 5,35 & 5,73 & 4,66 & 2,68 & 1,04 \\
\hline & Снежеток & 5,00 & 3,00 & 5,67 & 4,50 & 5,15 & 5,53 & 5,26 & 5,49 & 4,63 & 2,98 & 1,11 \\
\hline \multirow{3}{*}{$\begin{array}{l}\text { Отношение чисел } \\
\text { новорожденных девочек и } \\
\text { мальчиков }\end{array}$} & Яринское & 0,76 & 0,82 & 0,79 & 0,81 & 0,89 & 0,91 & 1,01 & 0,95 & 1,02 & 0,96 & 1,15 \\
\hline & Бисерово & & 1,25 & 1,18 & 0,92 & 0,91 & 1,12 & 0,87 & 1,02 & 0,99 & 0,91 & 0,86 \\
\hline & Снежеток & 0,54 & 0,43 & 0,55 & 0,67 & 0,93 & 0,88 & 0,85 & 0,89 & 0,91 & 0,81 & 0,86 \\
\hline \multirow{3}{*}{$\begin{array}{l}\text { Медианный возраст умерших в } \\
\text { возрасте старше } 15 \text { лет, лет }\end{array}$} & Яринское & 50 & 48 & 60 & 62 & 60 & 57 & 60 & 61 & 55 & 53 & 54 \\
\hline & Бисерово & & 58,5 & 60 & 52 & 61 & 57,5 & 62,5 & 60 & 54 & 54 & 51 \\
\hline & Снежеток & 65 & 49,5 & 60 & 60 & 60 & 61 & 60 & 55 & 54,5 & 60 & 55 \\
\hline \multirow{3}{*}{$\begin{array}{l}\text { Дожили и вступили в брак } \\
\text { мальчики, по годам рождения, \% }\end{array}$} & Яринское & 35,9 & 40,8 & 21,9 & 49,2 & 45,5 & 38,2 & 51,2 & 42,2 & 20,6 & & \\
\hline & Бисерово & & 23,1 & 17,0 & 22,5 & 20,0 & 31,2 & 25,7 & 20,7 & 3,9 & & \\
\hline & Снежеток & 6,3 & 7,1 & 17,4 & 26,7 & 36,2 & 29,0 & 18,7 & 17,3 & 4,9 & & \\
\hline $\begin{array}{l}\text { Дожили и вступили в брак } \\
\text { девочки, по годам рождения, \% }\end{array}$ & Яринское & 34,4 & 41,9 & 26,0 & 42,0 & 43,3 & 40,0 & 47,9 & 51,0 & 20,8 & & \\
\hline
\end{tabular}

